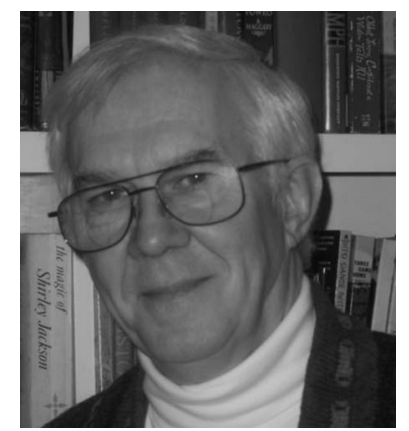

\section{Engineering at Home}

The azaleas have made their splash and their rhododendron relatives are cranking up for their big display. Then, in June, our gardens settle down to the long, hot days of an Atlanta summer. The show moves to the smaller perennial gardens with a few annuals to fill in the open spots. This comes about not by releasing our yard to the whims of nature, for that brings wisteria, honeysuckle, and weeds, but through hard work and engineering. For any "natural" garden is the product of technology and problem solving.

So, here's the lay of the land...literally. Our house fronts a street whose slope is steep enough that one side of our basement is fully exposed and the opposite side is buried. The lot is long and narrow, 100 by $500 \mathrm{ft}$ (30 by $150 \mathrm{~m}$ ), and the back half is in forest. The slope presents the problem. As some of our neighbors up the hill develop the back of their yards the runoff cascades across our gardens creating all sorts of havoc: plants in soggy soil, erosion, and minibogs.

It was not always like this. When we bought the house in 1973 the floor of the forest was overgrown with weeds, wisteria, and wild grapevine. It took some time before we rescued it. In the process we found the remnants of an old garden, but there was so little left that we started from scratch. Based on a loop trail that wound to the back, a landscape plan (Plan A) was devised that took advantage of the length of the lot. It was our intention that over 5 years we would install the gardens in the plan. Five years came and went and we had hardly begun.

We brought in a landscaper to carry out our 5-year plan in about 5 weeks. By this time our runoff problem had become evident, so we inserted a dry creek bed into the design to channel the water across the property. (Hydrological engineering.) We incorporated most of the initial plantings along the loop trail with two gardens near the house, then settled down to tend our newly decorated plot. This was the basis of our second 5-year plan. But then there was the ivy.

It grieves us to walk into a plant center (nursery would be too nice a word) and see English ivy for sale. Our reaction is, "They have no idea what they are getting into." In the center of the loop trail was a vast expanse of ivy. It climbed the trees, smothered the plants, and encroached on our newly planted gardens-botanical corrosion. After another 5 years we retired and just couldn't take it any longer. (Problem assessment.) The ivy had to go.

The runoff problem still existed and half measures weren't going to fix it. (Further assessment.) The landscape plan had to be revised. (Plan B.)

They took a Bobcat to the interior of the loop and rolled up balls of ivy $5 \mathrm{ft}$ in diameter. Although ivy in the area was removed, it didn't eradicate it. The price of freedom from ivy is eternal vigilance, a weeder, and a hand sprayer of Roundup. In Plan B we also put additional breaks in the slope by building a series of stone walls across it. In the ivy-cleared center, a large planting of rhododendrons, hydrangeas, and ferns was established. And above one of the upper stone walls, Helen designed and planted a White Garden-all of the blooms in it are white. Along with the new design, we rely on new technology in the form of Encore azaleas that bloom several times during the year, heating pads and miniature hot houses to quickly develop seedlings, and planters that can store large amounts of water for our tomatoes.

But just as with engineering projects, the gardens are subject to the whims and fortune of forces beyond our control: bugs, critters, and drought. And, as with projects, you compensate (irrigation), respond (pesticides), and sometimes ignore (critters) the obstacles to a trouble-free garden. The runoff problem is still not solved. After all our work we lost two beautiful rhodies to soggy roots. The fix, which has worked so far, was to put in a French drain (a ditch filled with volcanic rock) to channel the water around the garden center. Another tactic was to turn the problem into a solution by using the minibog created by the runoff for a planting of water-loving astilbes.

So, what do we get for all this? First, beautiful surprises: trilliums that have made their home under a native azalea, mountain laurel, whose blooms unfold in a magical manner, riots of azaleas, and small triumphs, like the glorious columbines, grown from seed, that bloom outside our study window. Next, we invite the neighborhood, the local joggers, and strangers admiring Atlanta's wonderful 
springtime to walk the garden. Finally, after dinner, glass of wine in hand, we take our walk through the garden to admire the plants and see what's bloomed and what's coming. Of course, I carry a little tape recorder with methere are always things to be done. (Quality control.)

\section{Donald C. O'Shea Editor}

P.S. If you would like to see something of our garden, there are some pictures at http://homepage.mac.com/ donoshea/Garden2007/. Clicking on one of the images enters a slide-show mode.

As I finished this editorial, I learned of a great loss to the SPIE community. Art Guenther died on April 21. Art understood both scientific research and politics and he worked long and hard to assure the support of research in science and engineering, going wherever the opportunity presented itself: Washington, Albuquerque, SPIE and OSA meetings, and the International Commission for Optics. His work as a member of SPIE's ESTEP committee for many years helped set the agenda for and move the Society's involvement in a range of advocacies.

Art was a traveler and a great one to travel with. At the opening reception of the SPIE's 50th anniversary celebration in San Diego, the Guenthers and O'Sheas decided to go on a Lewis and Clark tour on the Columbia and Snake Rivers. Last spring we took that trip and Joan and Art's comments and companionship made the trip more vivid and delightful. We will miss him. 